\title{
Some reflections on problem-based learning medical curriculum
}

This article was published in the following Dove Press journal: Advances in Medical Education and Practice

\author{
Alberto Enrique D’Ottavio \\ Rosario Medical School and Research \\ Council, Rosario National University, \\ Rosario, República Argentina
}

\section{Dear editor}

Given the promising results reported by Yadav et al, ${ }^{1}$ it seems timely to make some reflections, related to this article, for contributing to improving the hybrid problembased learning (PBL) curriculum carried out in our medical school, and in another ones where this kind of curriculum is being implemented.

In this regard, some facts for a better implementation may be considered. One of these lies in the belief that it is feasible to provide formative quality to medical students, with the number of entrants exceeding 350 per year and a teacher-student ratio near to 1:20. Furthermore, this landscape is likely to get darker provided students do not take a prior compensating course addressed to cope with their high school deficiencies, and hence acquiring basic content to learn the subsequent content, and facilitating a faster adaptation to a different learning strategy. In this context, it becomes clear that some basic conditions for a right PBL curriculum implementation may not have been completely satisfied. ${ }^{2}$

Other facts may be related with the implementation itself. For instance, (a) the lack of a suitable number of qualified tutors for carrying out one of the key activities of the SPICES model; ${ }^{3}$ (b) the limited number of professional teachers in respect to those with an unsuitable background; (c) the unfeasible integration of contents that, despite being attempted, collides with a significant number of students lacking fully developed abstract logical thinking; ${ }^{4}$ and (d) a pursued interdisciplinarity without prior and necessary disciplinary support.

Facing these challenges is essential for student benefit and a correct curriculum implementation.

\section{Disclosure}

The author reports no conflicts of interest in this communication.

\section{References}

1. Yadav RM, Piryani RM, Deo GP, Sha DK, Yadav LK, Islam MN. Attitude and perception of undergraduate medical students toward the problem-based learning in Chitwan Medical College, Nepal. Adv Med Educ Prac. 2018;9:317-322

2. Carrera LI, Tellez TE, D'Ottavio AE. Implementing a problem-based learning curriculum in an Argentinean medical school: implications for developing countries. Acad Med. 2003;78:1-4.

3. Harden RM, Sowden S, Dunn WR. Educational strategies in curriculum development: the SPICES model. Med Educ. 1984;18:284-297.

4. Bird L. Logical reasoning ability and student performance in General Chemistry. J Chem Educ. 2010;87:541-546.
Argentina

Email aedottavio@hotmail.com 
Dove Medical Press encourages responsible, free and frank academic debate. The content of the Advances in Medical Education and Practice 'letters to the editor' section does not necessarily represent the views of Dove Medical Press, its officers, agents, employees, related entities or the Advances in Medical Education and Practice editors. While all reasonable steps have been taken to confirm the content of each letter, Dove Medical Press accepts no liability in respect of the content of any letter, nor is it responsible for the content and accuracy of any letter to the editor.

Advances in Medical Education and Practice

Dovepress

\section{Publish your work in this journal}

Advances in Medical Education and Practice is an international, peerreviewed, open access journal that aims to present and publish research on Medical Education covering medical, dental, nursing and allied health care professional education. The journal covers undergraduate education, postgraduate training and continuing medical education research, and health care services. The manuscript management system is completely online and includes a very quick and fair peer-review system. Visit http://www.dovepress.com/testimonials.php to read real quotes from published authors.

Submit your manuscript here: http://www.dovepress.com/advances-in-medical-education-and-practice-journal 